\title{
Building Students' Learning Experience in Online Learning During Pandemic
}

\author{
Syaharuddin', Mutiani², Muhammad Rezky Noor Handy3, Ersis Warmansyah \\ Abbas 4, Jumriani 5
}

DOI: $10.35445 /$ alishlah.v13i2.796

Info Artikel Abstract

Keywords:

Online learning;

Learning experience;

Learning strategy

Kata kunci:

Pembelajaran online; Pengalaman belajar; Strategi pembelajaran
The practice of online learning during a pandemic is ideally able to provide independent learning for students. However, what happens is the loss of a meaningful learning experience. The research aims to describe the implementation of online learning in Banjarmasin and examine the selection of appropriate learning strategies in providing learning experiences for students. The data were sourced from structured interviews of as many as 15 students and five social studies teachers from 3 junior high schools. Structured interview data from the google form were tabulated, described, and analyzed by the social studies teacher in-depth interview through the restatement, description, and interpretation stages. The study results describe that choosing the right learning strategy has helped provide a learning experience for students during the pandemic. The learning strategy that can do is visiting teachers. Teacher visits are carried out with a clear schedule of regular attendance. In addition, teachers can take advantage of several platforms such as; zoom, google classroom, the personal messenger as learning media.

\begin{abstract}
Abstrak
Praktik pembelajaran online di masa pandemi idealnya mampu memberikan kemandirian belajar bagi peserta didik. Namun, faktual yang terjadi adalah hilangnya pengalaman belajar yang bermakna. Penelitian ini bertujuan untuk menguraikan implementasi pembelajaran online di Banjarmasin, dan menelaah pemilihan strategi pembelajaran yang tepat dalam memberikan pengalaman belajar bagi peserta didik. Data penelitian ini bersumber dari hasil wawancara terstruktur sebanyak 15 orang peserta didik, serta 5 orang guru mata pelajaran IPS dari 3 Sekolah Menengah Pertama. Data wawancara terstruktur dari google form ditabulasi dan dideskripsikan, data wawancara mendalam guru IPS dianalisis melalui tahapan restatement, description, dan interpretation. Hasil penelitian menguraikan bahwa pemilihan strategi pembelajaran yang tepat membantu telah memberikan pengalaman belajar bagi peserta didik selama pandemi. Adapun strategi pembelajaran yang dapat dilakukan adalah "guru kunjung”. Guru kunjung dilaksanakan dengan kejelasan jadwal kehadiran secara berkala. Di samping itu, guru dapat memanfaatkan beberapa platform seperti; zoom, google classroom, hingga
\end{abstract}

\footnotetext{
${ }^{1}$ Social Studies Education, Lambung Mangkurat University, Banjarmasin, Indonesia Email: syahar@ulm.ac.id

2 Social Studies Education, Indonesia University of Education, Bandung, Indonesia Email: mutiani@upi.edu

3 Social Studies Education, Lambung Mangkurat University, Banjarmasin, Indonesia

Email: rezky.handy@ulm.ac.id

4 Social Studies Education, Lambung Mangkurat University, Banjarmasin, Indonesia

Email: ersiswa@ulm.ac.id

5 Social Studies Education, Lambung Mangkurat University, Banjarmasin, Indonesia

Email: jumriani@ulm.ac.id
} 
pesan pribadi sebagai media pembelajaran. Pada praktiknya, guru dapat menyiapkan beberapa video pembelajaran yang relevan sebagai inovasi sumber belajar.

\section{INTRODUCTION}

Optimization of technology in learning continues to be driven in several countries, including Indonesia (Antoni, 2018; Lian, 2019; Sardiyanah, 2016). Technology is considered a threat because the current generation (generation $\mathrm{Z}$ ) is very dependent on gadgets for social media besides the "fever" online games that know no time (Turner, 2015). Technology as a threat is increasingly accurate when there is no good regulation from the government to search and disseminate various information vulnerable to misuse and dissemination of information whose contents cannot be accounted for (Hastini et al., 2020). Since the Covid-19 pandemic, technology has become a solution in learning (Afriansyah, 2020; Hidayat \& Noeraida, 2020; Jamaluddin et al., 2020). Technology provides ample space for students and teachers in learning practices. Online learning, utilizing various platforms such as zoom meetings, google classroom, Edmodo, quizzes, and e-learning, during the Covid-19 pandemic makes learning not limited to space and time. Technology has become a solution to learning for students and teachers during a pandemic when government policies have to study and work from home to reduce the spread of Covid-19.

Online learning during the pandemic does not entirely provide learning comfort for students as a meaningful learning experience. Restrictions on the space of students in online learning impact decreasing meaningfulness in their learning experiences, both in interacting with learning resources experiencing significant obstacles and obstacles in interacting with the broader environment, namely with fellow friends and with fellow friends with teachers. Students are no longer able to interact and discuss with their friends in completing school assignments. Communication with teachers also experienced obstacles due to online learning methods. These conditions require teachers to find new learning strategies so that students can continue to enjoy learning. Lase (2015), namely learning that is fun and meaningful (meaningful), the goals and learning outcomes can be achieved as expected. Online learning requires teachers to change learning strategies to create a fun learning experience for students during a pandemic.

The tendency of studies related to online learning does not see changes related to mental changes of students in learning as changes in their learning experiences, both changes in interacting with learning resources and interactions with fellow students and teachers. There are at least four dominant aspects of studies on online learning that are the focus of researchers. First, a study of the relationship between pandemics and learning identifies patterns of difficulties and limitations experienced by students and families in learning (Fatoni et al., 2020; Katz et al., 2021; Wan Hassan et al., 2020). Second, a study evaluates educational performance during a pandemic, including student achievement in learning (Ketmuni, 2021; Ramadhan et al., 2021). Third, studies that measure the performance of education and educational institutions during the pandemic (Purwanto, 2020; Rokhani, 2020; Russamsi et al., 2020). Fourth, a study that tries to look at the mental health conditions of students during a pandemic (Aamir \& Winkel, 2021). The trend of existing studies highlights learning as an aspect related to limited facilities and infrastructure, learning outcomes, and mental health that ignores students' learning experience as the main study.

This paper is intended to complement the shortcomings of previous studies on the relationship between online learning and student learning experiences that describe how students learn and deal with the changes that occur. In line with that, It will answer three questions in this study: (a) how is the condition of online learning infrastructure during the pandemic. (b) How to increase students' motivation in online learning during the pandemic. (c) How are online learning strategies through meaningful student learning experiences? These three questions will explain that online learning through new learning experiences for students requires new strategies by schools and teachers to achieve learning objectives. 
This paper argues that a new strategy is needed for teachers through a different learning experience to produce fun and meaningful learning for students during a pandemic (Lase, 2015). The limited access of students to online learning requires schools and teachers to make innovations in learning. Innovation is related to specific learning models and methods related to other aspects, such as; easy access to learning resources and cheap and affordable learning media. The research aims to describe the implementation of online learning in Banjarmasin and examine the selection of appropriate learning strategies in providing learning experiences for students. So that teachers can build motivation to learn through a more meaningful learning experience for students. The teacher's new strategy in online learning provides an exciting and meaningful learning experience for students.

\section{METHOD}

Research associates quantitative and qualitative approaches. In particular, the researchers combined the data from surveys and interviews. This matter provides in order to describe the research data. The research was conducted in Junior High School (SMP) in Banjarmasin city. It obtained the sources from 3 different schools with a total of 5 teachers and 15 students. Combining data from surveys and in-depth interviews with social studies teachers spread across three junior high schools (SMPs) was carried out in this study. Respondents were selected based on the status of teachers, namely as practical teachers (prospective teachers) who carried out field experience practices (PPL) in the three schools.

Meanwhile, students were randomly selected from three schools. Data is processed through reduction, display, and verification, as Miles and Huberman did (1992). First, the data collected is reduced to a summary based on the thematic and narrative stories from the respondents. In addition, the article contains data in the form of interview excerpts and graphic descriptions obtained from questionnaires via a google form. Then analyzed the data through three stages of analysis. First, a restatement of the data obtained, primarily through interviews, to maintain the authenticity of the field data. Second, a description technique is used to show the patterns and trends of the data, both interview and survey data. In the third stage, interpretation is carried out to draw both express and implied meanings from the data. A description technique is used to show the patterns and trends of the data, both interview and survey data. In the third stage, interpretation is carried out to draw both express and implied meanings from the data. A description technique is used to show the patterns and trends of the data, both interview and survey data. In the third stage, interpretation is carried out to draw both express and implied meanings from the data.

\section{FINDINGS AND DISCUSSION}

During the pandemic at the junior high school level in social studies subjects in Banjarmasin City, the implementation of online learning will be seen through some of the students' views regarding online learning, learning media, and online learning constraints. This study provides information that students enjoy participating in online learning (68\%). Although students stated that online learning was quite fun for them (68\%), but on the other hand, some of them (32\%) feel that the media (platform) used by teachers in online learning is less effective. The high percentage of students who enjoy learning online needs to be supported by suitable media to learn more effectively. In enjoying online learning, students utilize four media (platforms). The following is a description of the four media in question; 


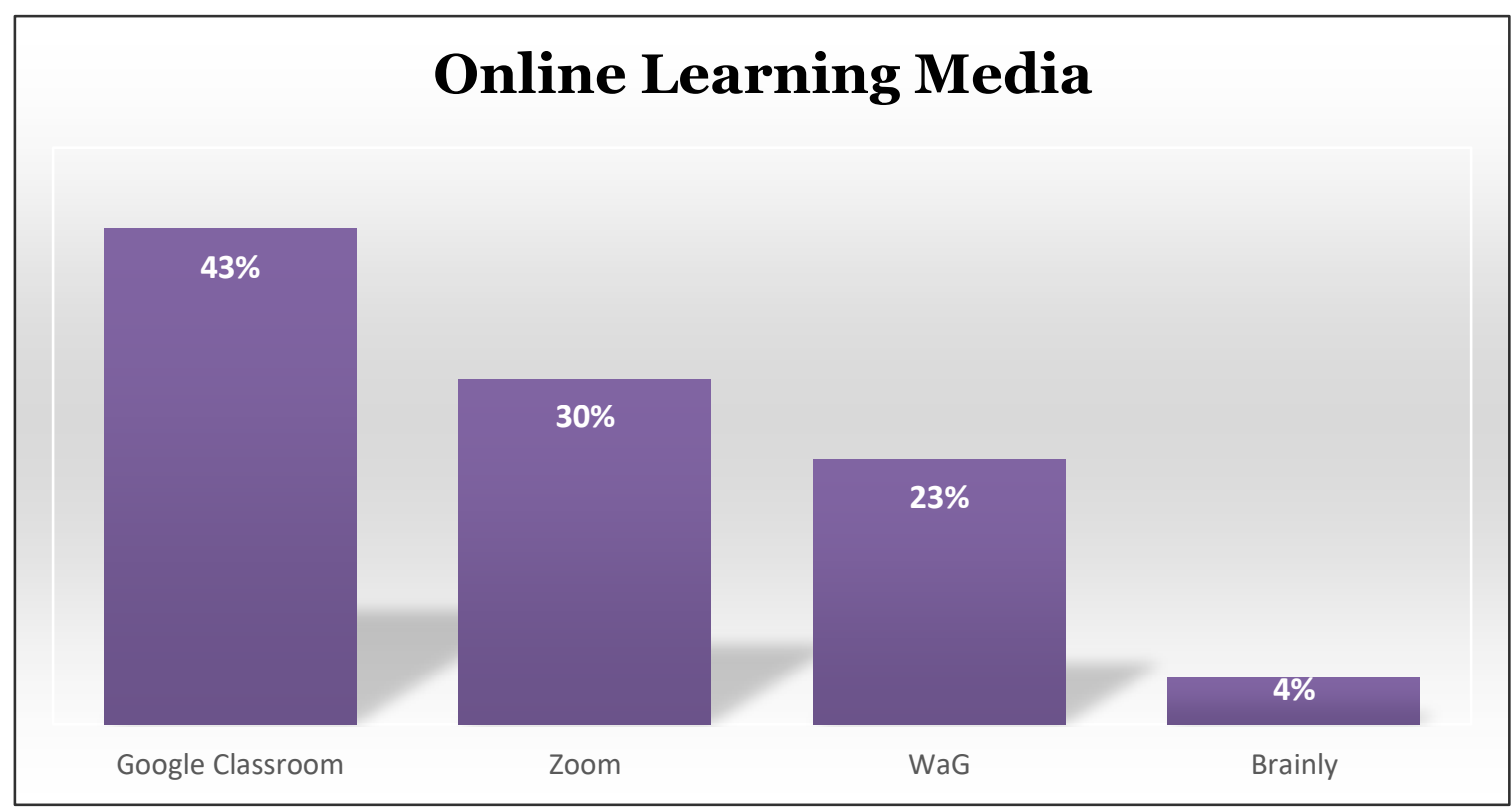

Figure 1. The most attractive online learning media (platform) for students

Teachers use many media in social studies learning during online learning during the Covid19 pandemic (Figure 1). Based on the data above, it is explained that the use of google classroom during online learning dominates with $43 \%$. Then, the two media used are zoom $30 \%$ and WhatsApp Group 23\%. The media that is rarely used is brainly. The use of media in learning leaves problems for students in participating in online learning. Therefore, media has a strategic meaning in learning during a pandemic to improve students' learning experience more meaningfully. In addition, the online learning problem is based on quotas and signals. According to RN (22 years old), another obstacle experienced by students during online learning is the availability of smartphone ownership (devices) and low enthusiasm for learning which is shown during class hours. Sometimes they also have other activities. This line with SN (21 years old) is as follows:

"The main obstacle for students in online learning is the low motivation of students to learn. It seems that students pay less attention when the teacher explains through the Zoom meeting platform. Students are also often late in collecting assignments. However, learning motivation appears again if students are given various methods and media, such as showing interesting videos and conducting questions and answers after explaining the material".

Based on interview data, the form of student motivation in learning during the pandemic through online learning will be explained regarding the level of success of teachers in building students' learning motivation. Here, online learning provides a better and exciting learning experience shown through understanding the material. According to $\mathrm{RN}$ ( 22 years old), related to building students' learning motivation, namely as follows:

"To understand online lessons, I ask students to ask more questions. In addition, students listen to the learning that I convey through learning media, such as; photos or learning videos. Then, students are asked to explain again what can take the material's content or learning from videos or photos that the teacher displays, so students must understand the learning material delivered by the teacher, sir". 


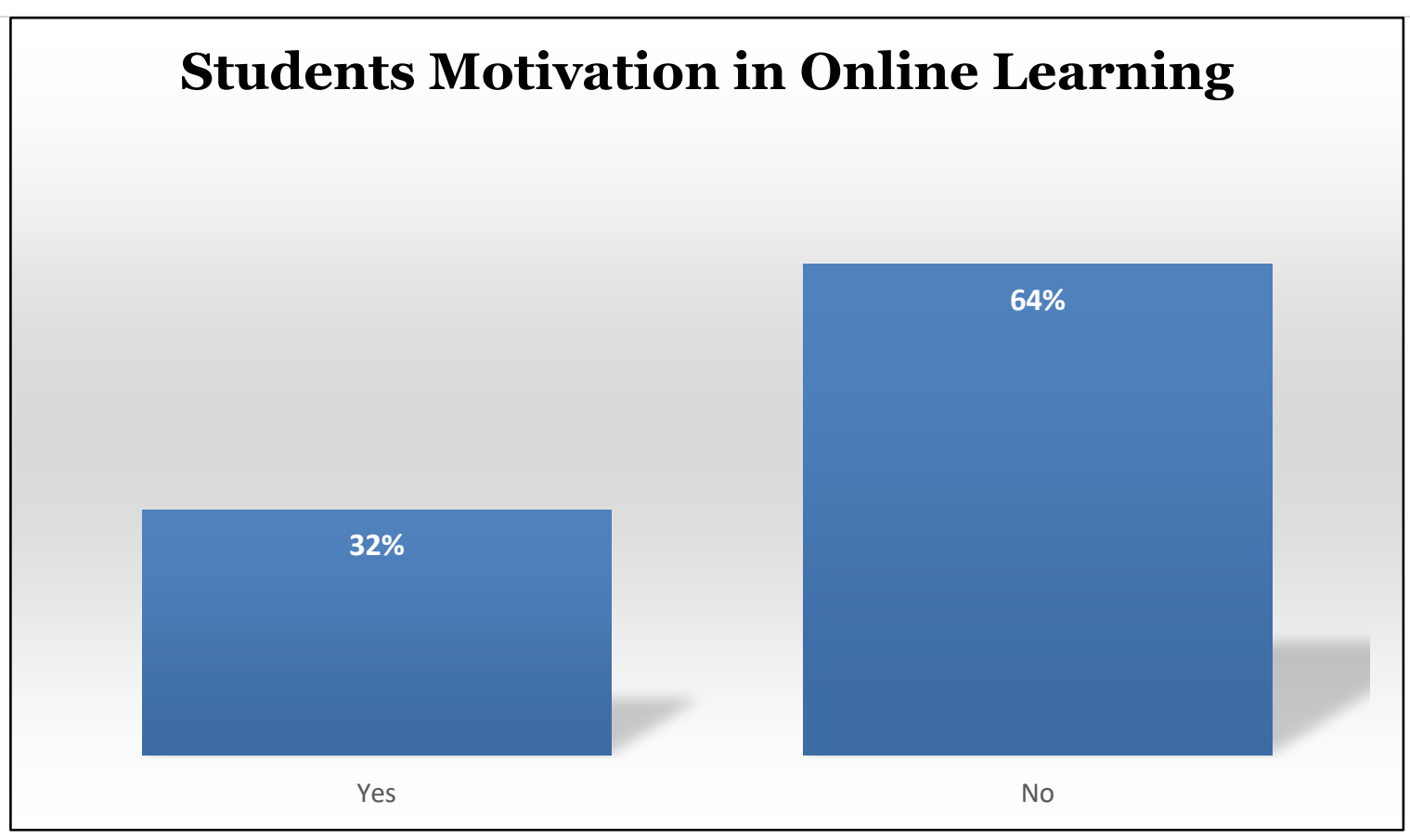

Figure 2. Students' learning motivation in online learning

Based on the data above, $64 \%$ of students stated that they were not motivated in online learning. Students feel the lack of teacher presence, so that learning is not meaningful. This matter reinforces that the presence of teachers cannot be replaced by the use of media (platforms). However, the media must be supported by the presence of the teacher in a different way. According to SN (21 years old), learning experiences are how to gain exciting knowledge and skills during online learning felt by students during the pandemic, namely when answering questions through the quizzes game. First, they say if quizzes are a new thing for them. An indication that they are pretty interested is that they ask that the game be repeated many times.

Another exciting thing is that students can find out the ranking after doing the quizzes to feel challenged. In addition to quizzes, to motivate students, ask questions after each explanation of the material. Then students are asked to look for information through the internet and students' books. Then play exciting videos related to the learning material. Creating engaging experiences during online learning needs to be formulated so that students feel that online learning provides a better/engaging learning experience through understanding the material.

Social studies teachers carry out new strategies to provide new learning experiences for students during online learning during the pandemic, especially students who do not have devices, by scheduling students to come to school. Expressed by SN (21 years old), that to overcome the device's limitations, she does this by scheduling students to come to school once a week to be given assignments and then handing them back to the teacher a week later. Thus, students come to school to receive assignments or several materials that they can do for one week. Online learning strategies during the pandemic do not always have to use technology (internet-based smartphones), especially for economically low students.

The time is given to do assignments for junior high school students during online learning. The data shows that $100 \%$ of students feel that they have enough time to read books, print media, watch videos, make reports on field observations/essays/papers, or others. On the other hand, the stress level of students during online learning in several places is relatively high due to the low time management of students to complete the tasks given. The overall exposure of the bar chart above describes the factual conditions of online learning. Conceptually, this study discusses the relationship between online learning and the learner's learning experience. Various teacher strategies that vary in online learning have provided a high spirit and motivation to learn. 
The enthusiasm and motivation provide a meaningful learning experience for students during online learning during the pandemic. However, there are still some obstacles in implementing online learning, such as infrastructure problems in signals, quotas, and the availability of devices for students. Second, students' motivation in learning is still low, such as students who are not severe when learning through the Zoom meeting platform. Hence, teachers need to formulate more varied strategies through various media, methods, learning resources, and evaluations in online learning. First, efforts are made to build students' learning motivation by social studies teachers, namely by making a schedule for meeting students and teachers at school once a week to provide materials or assignments and return assignments. Second, with the "visiting teacher" model, the teacher visits students' homes to provide material. Third, various learning strategies (methods, media, sources, evaluation) are applied by utilizing various media such as videos, pictures, and the internet. In addition, the discussion method is designed as attractive as possible and provides evaluations with the quizzes application to make learning more fun. Various social studies teacher strategies are needed to produce meaningful learning experiences in online learning during the pandemic to build students' learning motivation in various limitations.

The low learning motivation of students in online learning during the pandemic is caused by the low ability of teachers to design online learning to build more meaningful learning experiences. The ideals of online learning to produce meaningful learning experiences for students are not well developed. Teachers' still low digital literacy contributes to this problem (Asari et al., 2019; Kurnianingsih et al., 2017). Various ways have improved teacher digital literacy, such as participating in various training but have not significantly impacted. The government needs serious efforts so that teacher digital literacy continues to increase. Students are still dependent on teacher assistance in learning (Padli \& Rusdi, 2020). Improving teacher competence related to various things needed in online learning is an urgent matter that must be implemented.

Online learning during the pandemic, if associated with students' learning experience, shows two important meanings. First, the online learning process requires an adequate infrastructure (Astini, 2020; Atsani, 2020; Pujilestari, 2020). Adequate infrastructure provides convenience for students in online learning without finding signals, quota problems, and device ownership. Stakeholder support for this problem is the main thing. Second, the difficulties in online learning confirm that schools as institutions and teachers as individuals who have roles and responsibilities play an essential role in the smooth running of online learning during the pandemic (Winarsieh \& Rizqiyah, 2020; Zakariyah \& Hamid, 2020). Schools with all the infrastructure support are needed and innovative teachers who, among others, have digital literacy and high creativity. Asari et al. (2019) \& Kurnianingsih et al. (2017) provide a meaningful learning experience for students. Various factors largely determine the success of online learning. Full support by stakeholders, schools, and teachers is among the keys to supporting online learning success.

So far, the existing studies on online learning emphasize four things. First, the difficulty of online learning is related to the availability of technological devices (infrastructure). Inadequate instructional technology tools have been seen as a precondition (Astini, 2020; Atsani, 2020; Pujilestari, 2020). Second, a study that emphasizes the unpreparedness of students in accepting changes from face-to-face learning to online learning is done at home. Teacher absence has been assessed as a problem in learning (Padli \& Rusdi, 2020; Purwanto, 2020; Yuangga \& Sunarsi, 2020). Third, studies that measure the performance of education and educational institutions during the pandemic (Purwanto, 2020; Rokhani, 2020; Russamsi et al., 2020). Fourth, a study that tries to look at the mental health conditions of students during a pandemic (Aamir \& Winkel, 2021; Muslim, 2020). In contrast to the four trends above, this study looks more at online learning from learning strategies through new learning experiences for students. Online learning is nothing but a change in the teacher's strategy through new learning experiences to enjoy and remain meaningful. 
With the various problems described in online learning, the government and stakeholders must provide a more meaningful learning experience. Regulations related to infrastructure must prioritize the government and stakeholders to support online learning to reduce the difficulty of getting signals, quotas, and devices (Astini, 2020; Atsani, 2020; Pujilestari, 2020). The low level of teacher digital literacy competencies (Asari et al., 2019; Kurnianingsih et al., 2017). it should be a priority for the government and stakeholders to plan various training, workshops, and webinars to improve teacher digital literacy. Building a more meaningful learning experience for students through online learning can only be built through the availability of adequate infrastructure in addition to competent teachers and school (principal) support.

\section{CONCLUSION}

This study found that it turned out that the selection of the right teacher learning strategies had provided new learning experiences for students in online learning during the pandemic. Learning strategies through "visiting teachers," scheduling student attendance to school, learning through zoom meetings and WhatsApp media, preparing exciting videos and pictures, asking questions, utilizing the internet as a learning resource optimally, and selecting game-based evaluations, such as quizzes succeeded in building learning motivation of students as a new and more meaningful learning experience. Online learning requires teachers to be more innovative in designing learning to provide new learning experiences for students.

Students' learning experience experiences a shift in meaning during online learning during the pandemic. Learning resources are not simply chosen without considering appropriate learning strategies. The learning experience formed by the teacher is carried out through a new strategy that is different from the previous so that it gives new meaning to students in online learning. The utilization of internet-based media and learning resources is not always appropriate for online learning. Combining "conventional" media such as the "visiting teacher" method is the right strategy when online learning infrastructure is an obstacle that has been complained. The online learning infrastructure was not the main problem found in this study,

This study was limited to a small sample of only students and teachers and a few schools, which did not allow comparative analysis. In further research, at least two things must be developed: adding school categories and increasing the number of informants involved. Comprehensive analysis can only be done if there is a comparison. Therefore, this study suggests the need for a survey that accommodates the type of diverse school and involves personnel from schools, communities, and education leaders. In this way, we can obtain a more comprehensive and holistic portrait of the online learning experience during the pandemic.

\section{DAFTAR PUSTAKA}

Aamir, S., \& Winkel, C. (2021). The impact of Covid-19 on Saudi Arabian female students: an application of the CES-D depression scale. Journal of Educational and Social Research, 11(1), 23-31. https://doi.org/10.36941/jesr-2021-0003

Afriansyah, A. (2020). Covid-19, Transformasi Pendidikan dan Berbagai Problemnya. Pusat Penelitian Kependudukan LIPI, 24.

Antoni, A. (2018). Kejahatan Dunia Maya (Cyber Crime) Dalam Simak Online. Nurani: Jurnal Kajian Syari'ah Dan Masyarakat, 17(2), 127-140. https://doi.org/10.19109/nurani.v17i2.1192

Asari, A., Kurniawan, T., Ansor, S., Bagus, A., \& Rahma, N. (2019). Kompetensi Literasi Digital Bagi Guru Dan Pelajar Di. BIBLIOTIKA: Jurnal Kajian Perpustakaan Dan Informasi, 3(2), 98-104.

Astini, N. K. S. (2020). Pemanfaatan Teknologi Informasi dalam Pembelajaran Tingkat Sekolah Dasar pada Masa Pandemi Covid-19. Jurnal Lampuhyang, 11(2), 13-25.

Atsani, K. L. G. M. Z. (2020). Transformasi Media Pembelajaran Pada Masa Pandemi Covid-19. AlHikmah: Jurnal Studi Islam, 1(1), 82-93.

Fatoni, Arifiati, N., Nurkhayati, E., Nurdiawati, E., Fidziah, Pamungkas, G., Adha, S., Irawan, Purwanto, A., Julyanto, O., \& Azizi, E. (2020). University students online learning system 
during Covid-19 pandemic: Advantages, constraints and solutions. Systematic Reviews in Pharmacy, 11(7), 570-576. https://doi.org/10.31838/srp.2020.7.81

Hastini, L. Y., Fahmi, R., \& Lukito, H. (2020). Apakah Pembelajaran Menggunakan Teknologi dapat Meningkatkan Literasi Manusia pada Generasi $\mathrm{Z}$ di Indonesia? Jurnal Manajemen Informatika (JAMIKA), 1O(1), 12-28. https://doi.org/10.34010/jamika.v10i1.2678

Hidayat, D., \& Noeraida. (2020). Pengalaman Komunikasi Siswa Melakukan Kelas Online Selama Pandemi Covid - 19. JIKE: Jurnal Ilmu Komunikasi Efek, 3(2), 172-182.

Jamaluddin, D., Ratnasih, T., Gunawan, H., \& Paujiah, E. (2020). Pembelajaran Daring Masa Pandemik Covid-19 Pada Calon Guru: Hambatan, Solusi, dan Proyeksi. LP2M.

Katz, V. S., Jordan, A. B., \& Ognyanova, K. (2021). Digital inequality, faculty communication, and remote learning experiences during the COVID-19 pandemic: A survey of U.S. undergraduates. PLoS ONE, 16(2 February), 1-16. https://doi.org/10.1371/journal.pone.0246641

Ketmuni, M. (2021). The Acceptance of Online English Language Learning of Undergraduate Students at Rajamangala University of Technology Thanyaburi. Psychology and Education Journal, 58(1), 1464-1470. https://doi.org/10.17762/pae.v58i1.930

Kurnianingsih, I., Rosini, R., \& Ismayati, N. (2017). Upaya Peningkatan Kemampuan Literasi Digital Bagi Tenaga Perpustakaan Sekolah dan Guru di Wilayah Jakarta Pusat Melalui Pelatihan Literasi Informasi. Jurnal Pengabdian Kepada Masyarakat (Indonesian Journal of Community Engagement), 3(1), 61. https://doi.org/10.22146/jpkm.25370

Lase, F. (2015). Dasar Pengembangan Kurikulum Menjadi Pengalaman Belajar. Jurnal Obsesi: Jurnal Pendidikan Anak Usia Dini, 1(2), 130-140.

Lian, B. (2019). Revolusi Industri 4.o Dan Disrupsi, Tantangan Dan Ancaman Bagi Perguruan Tinggi. Prosiding Seminar Nasional Pendidikan Program Pascasarjana Universitas Pgri Palembang 12 Januari 2019.

Miles, M. B., \& Huberman, A. M. (1992). Analisis Data Kualitatif. UI Press.

Muslim, M. (2020). Manajemen Stress pada Masa Pandemi Covid-19. Jurnal Manajemen Bisnis, 23(2), 192-201.

Padli, F., \& Rusdi. (2020). Respon Siswa dalam Pembelajaran Online Selama Pandemi. Social Landscape Journal, 1(3), 1-7.

Pujilestari, Y. (2020). Dampak Positif Pembelajaran Online Dalam Sistem Pendidikan Indonesia Pasca Pandemi Covid-19. Adalah: Buletin Hukum Dan Keadilan, 4(1), 49-56.

Purwanto, A. (2020). Studi eksplorasi Dampak WFH Terhadap Kinerja Guru. Journal of Education, Psychology and Counseling, 2(1), 92-100.

Ramadhan, I., Pantjawati, A. B., \& Juanda, E. A. (2021). Analysis of Learning Model and Learning Understanding of High School Students in Craft Subject Using an Online Learning System. In 6th UPI International Conference on TVET 2020 (TVET 2020), 520, 236-239. https://doi.org/10.2991/assehr.k.210203.124

Rokhani, C. T. S. (2020). Pengaruh Work From Home (WFH) Terhadap Kinerja Guru SD Negeri Dengkek o1 Pati Selama Masa Pandemi Covid-19. EduPsyCouns: Journal of Education, Psychology and Counseling, 2(1), 424-437.

Russamsi, Y., Hadian, H., \& Nurlaeli, A. (2020). Pengaruh Kepemimpinan Kepala Sekolah Dan Peningkatan Profesional Guru Terhadap Kinerja Guru Di Masa Pandemi Covid-19. MANAGERE: Indonesian Journal of Educational Management, 2(3), 244-255. https://doi.org/10.52627/ijeam.v2i3.41

Sardiyanah, S. (2016). Dampak Globalisasi Terhadap Pendidikan. Jurnal Al-Qalam: Jurnal Kajian Islam \& Pendidikan, 8(2). https://doi.org/10.47435/al-qalam.v8i2.237

Turner, A. (2015). Generation Z: Technology and Social Interest. The Journal of Individual Psychology, 71(2), 103-113. https://doi.org/10.1353/jip.2015.0021

Wan Hassan, W. A. S., Ariffin, A., Ahmad, F., Sharberi, S. N. M., Nor Azizi, M. I., \& Zulkiflee, S. N. 
(2020). Covid-19 pandemic: Langkawi vocational college student challenge in using google classroom for teaching and learning (t\&l). International Journal of Advanced Trends in Computer Science and Engineering, 9(3), 3299-3307. https://doi.org/10.30534/ijatcse/2020/127932020

Winarsieh, I., \& Rizqiyah, I. P. (2020). Peranan guru dalam pembelajaran daring pada masa pandemi covid-19. Indonesia Journal of Teacher Education, 1(4), 159-164.

Yuangga, K. D., \& Sunarsi, D. (2020). Pengembangan media dan strategi pembelajaran untuk mengatasi permasalahan pembelajaran jarak jauh di pandemi covid-19. JGK (Jurnal Guru Kita), 4(3), 51-58.

Zakariyah, A., \& Hamid, A. (2020). Kolaborasi Peran Orang Tua dan Guru dalam Pembelajaran Pendidikan Agama Islam Berbasis Online di Rumah. Intizar, 26(1), 17-26. https://doi.org/10.19109/intizar.v26i1.5892 